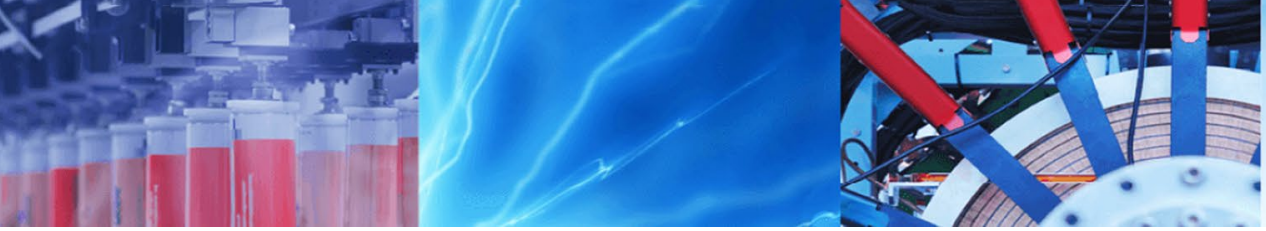

Research Article

\title{
Density functional theory studies of Hypaphorine from Erythrina mildbraedii and Erythrina addisoniae: structural and biological properties
}

\author{
Emmanuel Talla ${ }^{4}$ Marthe Carine Djuidje Fotsing ${ }^{1} \cdot$ Musa Bunu Ismaila ${ }^{1}$. Charlotte Mungho Tata ${ }^{1}$. \\ Monisola Itohan Ikhile ${ }^{1}$. Lydia Rhyman ${ }^{1,5}$. Charmaine Arderne ${ }^{3} \cdot$ Nicolette Niemann $^{2}$. Ponnadurai Ramasami ${ }^{1,5}$. \\ Derek Tantoh Ndinteh ${ }^{1}$
}

Received: 23 July 2019 / Accepted: 10 February 2020 / Published online: 17 February 2020

(c) Springer Nature Switzerland AG 2020

\begin{abstract}
This study was aimed at isolating hypaphorine from Erythrina mildbraedii Harms (Fabaceae) and Erythrina addisioniae Hutch. \& Datziel (Fabaceae) in order to determine its structural and antibacterial effects. Density functional theory (DFT) calculations and X-ray crystallographic analysis of the isolated hypaphorine was determined. The antibacterial effects of hypaphorine against a number of Gram positive and Gram negative bacterial strains were investigated. The root mean square deviation between the experimental and calculated bond lengths and bond angles of hypaphorine were found to be $0.046 \AA$ and $1.5^{\circ}$ respectively. The highest occupied molecular orbital (HOMO) of hypaphorine was delocalised on the indole moiety whereas the lowest occupied molecular orbital (LUMO) was delocalised on the $-\mathrm{N}\left(\mathrm{CH}_{3}\right)_{3}$ group and the HOMO-LUMO gap of hypaphorine was $4.65 \mathrm{eV}$. Hypaphorine inhibited the growth of the Gram-positive bacteria tested, namely Bacillus cereus, B. subtilis, Staphylococcus aureus and S. epidermidis. The lowest minimum inhibitory concentration (MIC) value of $2 \mathrm{mg} / \mathrm{mL}$ was exhibited against Mycobacterium smegmatis, Staphylococcus aureus and B. subtilis. The theoretical and experimental results from this study showed that hypaphorine is capable of forming quadrupole moments thus explaining its antibacterial effects on Gram positive bacteria.
\end{abstract}

Electronic supplementary material The online version of this article (https://doi.org/10.1007/s42452-020-2228-z) contains supplementary material, which is available to authorized users.

Derek Tantoh Ndinteh, dndinteh@uj.ac.za| 'Department of Applied Chemistry, University of Johannesburg, PO Box 17011, Doornfontein, Johannesburg 2028, South Africa. ${ }^{2}$ Department of Biotechnology and Food Technology, University of Johannesburg, PO Box 17011, Doornfontein, Johannesburg 2028, South Africa. ${ }^{3}$ Department of Chemistry, University of Johannesburg, PO Box 524 Auckland Park, Johannesburg 2006, South Africa. ${ }^{4}$ Department of Chemistry, University of Ngaoundere, PO Box 454, Ngaoundere, Cameroon. ${ }^{5}$ Computational Chemistry Group, Department of Chemistry, Faculty of Science, University of Mauritius, Réduit 80837 , Mauritius. 


\section{Graphic abstract}

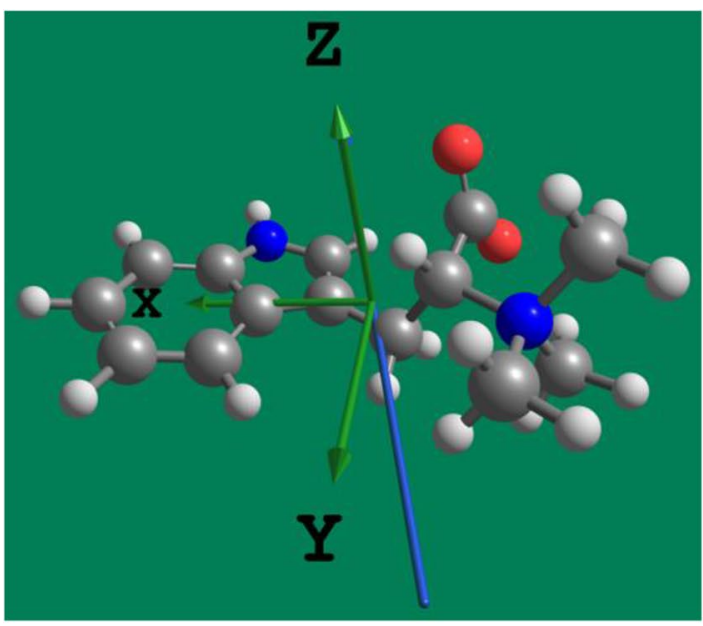

Hypaphorine

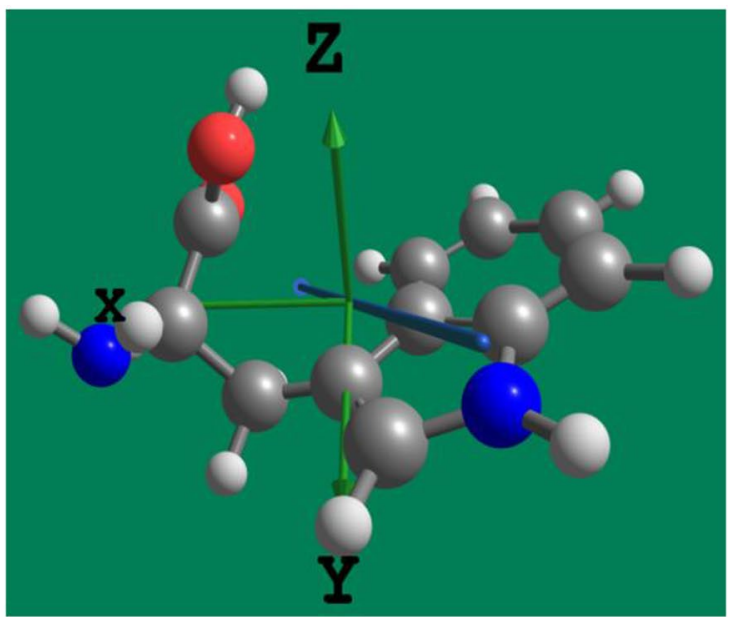

L-Tryptophan

\begin{tabular}{|l|c|c|}
\cline { 2 - 3 } \multicolumn{1}{c|}{} & Hypaphorine & Tryptophan \\
\hline Dipole moment (D) & 8.177 & 3.073 \\
\hline Quadrupole moment (D $\AA$ ) & -15.640 & -5.191 \\
\hline
\end{tabular}

Keywords Hypaphorine · Erythrina mildbraedii · Erythrina addisoniae $\cdot$ Crystal structure $\cdot$ Antibacterial · Density functional theory

\section{Introduction}

Hypaphorine (also known as lenticin, with the IUPAC name (2S)-3-(1H-indol-3-yl)-2-(trimethylazaniumyl) propanoate is an indole alkaloid (Fig. 1). It was first isolated and characterized from Erythrina hypaphorus Boerl. Ex Koord.-Schum in 1911 [1] and since has been found in a large number of different organisms ranging from plants to fungi, sponges and mammals. It has been isolated from plant species mainly in the Fabaceae family as well as beetroots and carrots [1-5]. Hypaphorine is structurally similar to a number of biochemically active compounds such as the plant hormone indole-3-acetic acid (IAA), tryptophan, melatonin and seratonin [5-7] (Figure 1S) and therefore, it has been found to be of potential medicinal value $[4,5]$. It can act as a competitive inhibitor for a number of processes controlled by IAA [8-10].

Erythrina is a prominent source of phytoconstituents and medicinal agents [9]. They are widely known for their symbiotic relationships with mycorrhizal fungi. The presence of hypaphorine in the roots of these plants inhibit root hair formation and stimulates curling of the roots which aids in these symbiotic relationships [7]. Hypaphorine has thus been detected in a number of ectomycorrhizal fungal species like Pisolithus tinctorius [1, 11, 12]. In these symbiotic relationships, hypaphorine inhibits the effect of IAA in the fungi by blocking membrane-bound IAA receptors thus inducing abnormal proliferation of hyphae that extend intracellularly into plant tissues.

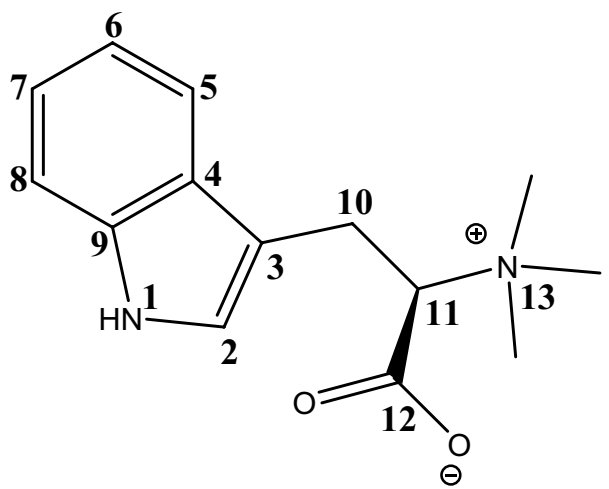

Fig. 1 Hypaphorine and its atom numbering 
Bacteria growing in the mycorrhizosphere of symbionts such as $P$. tinctorius may stimulate the production hypaphorine [13].

To the best of our knowledge, the crystal structure of hypaphorine and its antibacterial activity have not been investigated. Therefore, in this work, hypaphorine was isolated from Erythrina mildbraedii Harms (Fabaceae) and Erythrina addisioniae Hutch. \& Datziel (Fabaceae), its crystal structure, geometric parameters and antibacterial activities were determined. The energy gap between the highest occupied molecular orbital (HOMO) and the lowest unoccupied molecular orbital (LUMO) was obtained by theoretical calculations based on DFT-optimized conformation. DFT method are used to complement experimental investigations involving natural products $[12,14,15]$.

\section{Experimental}

\subsection{Materials and bacterial strains}

The following bacterial strains were obtained from Davies Diagnostics: Gram-positive bacteria: Bacillus cereus (ATCC 10876), B. subtilis (ATCC 19659), Enterococcus faecalis (ATCC 13047), Mycobacterium smegmatis mc2 155, Staphylococcus epidermidis (ATCC 14990) and S. aureus (ATCC 25923). Gram-negative bacteria: Enterobacter cloacae (ATCC 13047), Escherichiacoli (ATCC 25922), Klebsiella oxytoca (ATCC 8724), K. pneumonia (ATCC 13882), Proteus mirabilis (ATCC 7002), P vulgaris (ATCC 6380) and Pseudomonas aeruginosa (ATCC 27853). All strains were confirmed purity stock cultures and maintained in the Biotechnology laboratories of the University of Johannesburg. Mueller-Hinton agar and Mueller-Hinton broth were obtained from Oxoid. Nalidixic acid was bought from Sigma.

Stem bark of E. addisoniae and E. mildbraedii were collected from trees in Yaounde (Centre region of Cameroon) and Buea (South West region of Cameroon) that had been used previously $[16,17]$. The stem barks were identified and compared to existing voucher specimens of E. addisoniae (No. 41617/HNC) and E. mildbraedii (No. 50452/HNC) by Mr. Victor Nana, a botanist at the Cameroon National Herbarium (Yaoundé, Cameroon).

Column chromatography (CC) was carried out using Merck silica gel $60 \mathrm{PF}_{254}$ and silica gel 60, respectively. For TLC Merck precoated silica gel $60 \mathrm{~F}_{254}$ plates were used. Spots on TLC were visualized under UV light and by spraying with anisaldehyde- $\mathrm{H}_{2} \mathrm{SO}_{4}$ reagent followed by heating.

All NMR work was done on a Bruker Avancell $(400 \mathrm{MHz})$ and a Bruker Avancell ( $500 \mathrm{MHz}$ ), with TMS or residual solvent peaks as a reference.

\subsection{Hypaphorine extraction and its purification}

The method by Wandji and coworkers [18] was adapted. The plant material was dried, finely ground into powder and extracted at room temperature $(10 \mathrm{~g}$ plant material/150 mL solvent) with a 50:50 methanol:chloroform solution. The solvent was replaced daily. After 3 days the pooled solvent was filtered and concentrated at $35^{\circ} \mathrm{C}$ using a rotary evaporator under reduced pressure.

The crude extract was subjected to gravity column chromatography on silica gel, using a gradient solvent system of cyclohexane, $\mathrm{CH}_{2} \mathrm{Cl}_{2}$, EtOAc and $\mathrm{MeOH}$ in increasing proportions of the polar solvent to yield fractions. The fractions were characterized on $\mathrm{TLC}$ using $\mathrm{CH}_{2} \mathrm{Cl}_{2}-\mathrm{MeOH}$, 6.5:3.5. Similar fractions were pooled and concentrated at $35^{\circ} \mathrm{C}$ using a rotary evaporator. The remaining solvents were allowed to evaporate in a desiccator and the resulting crystals were subjected to $1 \mathrm{D}$ and 2D NMR analysis to positively identify hypaphorine [19].

\subsection{Crystallography: data collection}

A colourless block-like crystal with approximate dimensions $0.174 \times 0.265 \times 0.317 \mathrm{~mm}^{3}$ was selected under oil under ambient conditions and attached to the tip of a MiTeGen MicroMount $\odot$. The crystal was mounted in a stream of cold nitrogen at 100 (1) K and centred in the X-ray beam by using a video camera. The crystal evaluation and data collection were performed on a Bruker APEXII CCD diffractometer with Mo Ka radiation $(\lambda=0.71073 \AA)$ and the diffractometer to crystal distance of $4.96 \mathrm{~cm}$.

The initial cell constants were obtained from three series of $\omega$ scans at different starting angles. Each series consisted of 15 frames collected at intervals of $0.4^{\circ}$ in a $6^{\circ}$ range about $\omega$ with the exposure time of $10 \mathrm{~s}$ per frame. The reflections were successfully indexed by an automated indexing routine built in the APEXII program suite. The final cell constants were calculated from a set of 823 strong reflections from the actual data collection. The data were collected by using the full sphere data collection routine to survey the reciprocal space to the extent of a full sphere to a resolution of $0.75 \AA$. A total of 18,498 reflections were harvested by collecting 7 sets of frames with $0.5^{\circ}$ scans in $\omega$ and $\varphi$ with exposure times of $10 \mathrm{~s}$ per frame. These highly redundant datasets were corrected for Lorentz and polarization effects. The absorption correction was based on fitting a function to the empirical transmission surface as sampled by multiple equivalent measurements [20]. 


\subsection{Computer programs used to collect data, solve and refine the structure}

Data collection-BRUKER APEXII; Structure solutionSHELXS [21, 22]; Data reduction-BRUKER SAINT and SADABS [20]; Structure refinement-SHELXL [21, 22]; Structure manipulation and molecular graphics-OLEX2 [23] and Structure checking-PLATON [24].

\subsection{Antibacterial tests: disk diffusion essay}

The method described by Othman et al. was adapted [25]. Overnight bacterial cultures (of the 14 strains listed above) grown in Mueller-Hinton broth were diluted to match a 0.5 McFarland standard. A sterile swab was dipped into the bacterial culture and used to closely streak the bacteria onto $20 \mathrm{~mL}$ Mueller-Hinton agar in a petri dish. Discs containing $500 \mu \mathrm{g}$ antibiotic or hypaphorine were placed on the seeded agar plates and the plates were incubated at $37^{\circ} \mathrm{C}$ for $24 \mathrm{~h}$. Each experiment was repeated five times. Zones of inhibition were measured and reported in $\mathrm{mm}$.

\subsection{Minimum inhibitory concentration}

The minimum inhibitory concentration of hypaphorine was determined against the five bacterial strains that showed activity in the disc diffusion assay (B. cereus, B. subtilis, M. smegmatis, S. aureus and S. epidermis). The method reported by Andrew [26] was followed. All tests were repeated five-fold. A stock solution of hypaphorine was prepared at $32 \mathrm{mg} / \mathrm{mL}$ in methanol, and serially diluted with sterile Mueller-Hinton broth. The antibiotic nalidixic acid was also prepared $(32 \mathrm{mg} / \mathrm{mL})$ and serially diluted in the same way to act as control. $100 \mu \mathrm{L}$ aliquots of the serially diluted hypaphorine solutions or antibiotic dilutions were pipetted into individual wells of a microtitre plate. $100 \mu \mathrm{L}$ of a bacterial suspension (diluted to yield an inoculum size of 106 CFU's) was added to each well. The plates were incubated at $37^{\circ} \mathrm{C}$ for $16 \mathrm{~h} .10 \mu \mathrm{L}$ of a $0.02 \%(\mathrm{w} / \mathrm{v})$ of resazurin sodium salt solution was added to each well and the plates were re-incubated at $37^{\circ} \mathrm{C}$ for $2 \mathrm{~h}$. Color change from blue to pink indicated live bacterial cultures. To confirm viability of the bacterial cultures 100 $\mu \mathrm{L}$ of sterile Mueller-Hinton broth was mixed with $100 \mu \mathrm{L}$ bacterial suspension in five wells.

\subsection{Computational methodology}

Hypaphorine was optimised using the DFT method with the B3LYP functional $[27,28]$ in conjunction with the $6-311++G(d, p)$ basis set [29] for all atoms. Full optimisation, without any symmetry restrictions, was carried out in the gas phase using the tight criteria. Frequency computation of the optimised geometry was also performed to ensure that the optimised structure was a true local minimum. In order to mimic the experimental NMR conditions, hypaphorine was also optimised in water as the solvent. The solvent computations were carried out using the polarizable continuum model as developed by Tomasi's group $[30,31]$ in the framework of self-consistent reaction field. The optimized structure in water was used for computing chemical shifts with the Gauge-Including Atomic Orbital method [32] using shieldings of TMS computed at the same theoretical level and basis set. Gaussian 09 program [33] was used for all the computations by means of the resources provided by Gridchem [34, 35].

Table $1{ }^{1} \mathrm{H}(400 \mathrm{MHz})$ and ${ }^{13} \mathrm{C}(100 \mathrm{MHz})$ NMR spectral data $\delta$, multiplicity, J) of hypaphophrine in $\mathrm{D}_{2} \mathrm{O}$

\begin{tabular}{|c|c|c|c|c|c|c|c|c|c|c|}
\hline \multirow{2}{*}{\multicolumn{2}{|c|}{$\begin{array}{l}\text { Atom label- } \\
\text { ling } / \Delta \delta \mathrm{c} /\end{array}$}} & \multicolumn{2}{|c|}{ Experiment } & \multicolumn{2}{|l|}{ Computed } & \multirow{2}{*}{$\begin{array}{l}\text { Experiment } \\
\delta^{1} \mathrm{H}(\mathrm{m}, J=\mathrm{Hz})\end{array}$} & \multirow{2}{*}{ Computed } & \multirow[b]{2}{*}{$/ \Delta \delta_{H} /$} & \multirow[t]{2}{*}{ Chem draw } & \multirow{2}{*}{$\begin{array}{l}/ \Delta \delta_{H} / \\
/ \Delta \delta_{H} /\end{array}$} \\
\hline & & & Chem draw & $\delta^{13} \mathrm{C}$ & $/ \Delta \delta c /$ & & & & & \\
\hline 1 & & - & & - & & $10.17 \mathrm{~s}$ & $8.06(8.47)^{a}$ & 2.11 & 10.88 & 0.68 \\
\hline 2 & 1.78 & 124.68 & 122.9 & 131.87 & 9.19 & $7.16 \mathrm{~s}$ & 7.27 & 0.11 & 7.18 & 0.08 \\
\hline 3 & 3.73 & 107.07 & 110.8 & 117.22 & 10.15 & - & - & - & & \\
\hline 4 & 0.99 & 126.41 & 127.4 & 135.10 & 8.69 & - & - & - & & \\
\hline 5 & 0.52 & 119.42 & 118.9 & 124.52 & 5.10 & $7.61 \mathrm{~d} 8.05$ & 8.03 & 0.42 & 7.58 & 0.03 \\
\hline 6 & 0.16 & 122.04 & 122.2 & 126.16 & 4.10 & 7.17 t 8.00 & 7.45 & 0.28 & 6.97 & 0.20 \\
\hline 7 & 1.86 & 118.14 & 120.0 & 128.45 & 10.31 & 7.24 t 8.05 & 7.51 & 0.27 & 7.13 & 0.11 \\
\hline 8 & 0.91 & 112.01 & 111.1 & 117.81 & 5.80 & $7.48 \mathrm{~d} 8.05$ & 7.68 & 0.20 & 7.34 & 0.14 \\
\hline 9 & 0.28 & 136.12 & 136.4 & 144.42 & 8.30 & - & - & - & & \\
\hline 10 & 1.68 & 22.73 & 24.4 & 28.87 & 6.14 & $3.21 \mathrm{~d} 6.8$ & $3.22,3.40$ & 0.01 & 3.293 .04 & 0.05 \\
\hline 11 & 1.96 & 78.86 & 16.9 & 87.18 & 8.32 & 3.81 t 6.8 & 3.81 & 0.00 & 4.82 & 1.01 \\
\hline 12 & 0.2 & 171.40 & 171.6 & 177.42 & 6.02 & - & - & & & \\
\hline 13 & 0.01 & 51.91 & 51.9 & $48.92-56.89$ & $2.99-4.98$ & $3.16 \mathrm{~s}$ & $2.57-4.84$ & $0.59-1.68$ & 3.30 & 0.14 \\
\hline
\end{tabular}

${ }^{a}$ Computed using the M06-2X/6-311++G(d,p) method 
Table 2 Crystallographic data of hypaphorine

\begin{tabular}{|c|c|}
\hline \multicolumn{2}{|l|}{ Crystal data } \\
\hline Chemical formula & $\mathrm{C}_{14} \mathrm{H}_{18} \mathrm{~N}_{2} \mathrm{O}_{2}$ \\
\hline$M_{\mathrm{r}}$ & 246.30 \\
\hline Crystal system, space group & Orthorhombic, $P 2_{1} 2_{1} 2_{1}$ \\
\hline Temperature (K) & 100 \\
\hline$a, b, c(\AA)$ & $9.517(4), 10.784(4), 12.422(4)$ \\
\hline$V\left(\AA^{3}\right)$ & $1274.8(8)$ \\
\hline$Z$ & 4 \\
\hline Radiation type & Mo Ka \\
\hline$\mu\left(\mathrm{mm}^{-1}\right)$ & 0.09 \\
\hline Crystal size (mm) & $0.32 \times 0.27 \times 0.17$ \\
\hline \multicolumn{2}{|l|}{ Data collection } \\
\hline Diffractometer & Bruker APEX-II CCD diffractometer \\
\hline Absorption correction & $\begin{array}{l}\text { Numerical SADABS } 2012 / 1 \text { (Bruker, 2012) was used for absorption correc- } \\
\text { tion. wR2(int) was } 0.0563 \text { before and } 0.0511 \text { after correction. The Ratio } \\
\text { of minimum to maximum transmission is } 0.9319 \text {. The } \lambda / 2 \text { correction } \\
\text { factor is } 0.0015 \text {. }\end{array}$ \\
\hline$T_{\min }, T_{\max }$ & $0.884,0.949$ \\
\hline $\begin{array}{l}\text { No. of measured, independent and observed }[I>2 \sigma(I)] \text { reflec- } \\
\text { tions }\end{array}$ & $18,498,3230,2919$ \\
\hline$R_{\text {int }}$ & 0.042 \\
\hline$(\sin \theta / \gamma)_{\max }\left(\AA^{-1}\right)$ & 0.672 \\
\hline \multicolumn{2}{|l|}{ Refinement } \\
\hline$R\left[F^{2}>2 \sigma\left(F^{2}\right)\right], w R\left(F^{2}\right), S$ & $0.034,0.079,1.05$ \\
\hline No. of reflections & 3230 \\
\hline No. of parameters & 171 \\
\hline $\mathrm{H}$-atom treatment & $\mathrm{H}$ atoms treated by a mixture of independent and constrained refinement \\
\hline$\Delta_{\max } \Delta_{\min }\left(\mathrm{e} \AA^{-3}\right)$ & $0.24,-0.19$ \\
\hline Absolute structure & Refined as an inversion twin. \\
\hline Absolute structure parameter & $0.3(13)$ \\
\hline
\end{tabular}

\section{Results and discussion}

\subsection{Hypaphorine from Erythrina genus}

NMR results positively identified hypaphorine in the stem bark of both $E$. addisoniae and E. mildbraedii. ${ }^{1} \mathrm{H}$ and ${ }^{13} \mathrm{C}$ NMR spectral data were in agreement with literature [18, 19] and are presented in Table 1. Computed NMR parameters are also presented in Table 1 and in general, there is a good correlation between the experimental and theoretical chemical shifts. Both species are indigenous to West Africa and are used as medicinal plants to treat a number of ailments. Isoflavonoids from this species have shown PTP1B inhibition and cytotoxic activity, which give the plant potential to be used as anticancer treatment [16, 17]. Extracts from E. mildbraedii are used to treat stomach problems and various diseases associated with bacterial infection, asthma, female infertility, ulcers, and inflammations [36, 37]. Plant foods from the Fabaceae family such as peanuts, chickpeas or lentils contain high levels of hypaphorine. It was also detected in the bloodstream and in human breast milk after the consumption of food containing this compound [4].

\subsection{Crystal structure and DFT results}

Crystal data, data collection, structure refinement details and resolved final structure are summarized in Table 2. CCDC-1401794 contains the supplementary crystallographic data for this paper. This data can be obtained free of charge at http://www.ccdc.cam.ac.uk. The systematic absences in the diffraction data are consistent for the orthorhombic chiral space group P2 $2_{1} 2_{1} 2_{1}$. The e-statistics also confirm this non-centrosymmetric space group and yield chemically reasonable and computationally stable results of refinement [21,22]. A successful solution by the direct methods in the program SHELXS $[21,22]$ within the crystallographic program OLEX2 [23] provide most non-hydrogen atoms from the electron density map. 
Fig. 2 Packing of Hypaphorine viewed down the $b$-axis. Red dashed line indicates the hydrogen bond that directs the packing

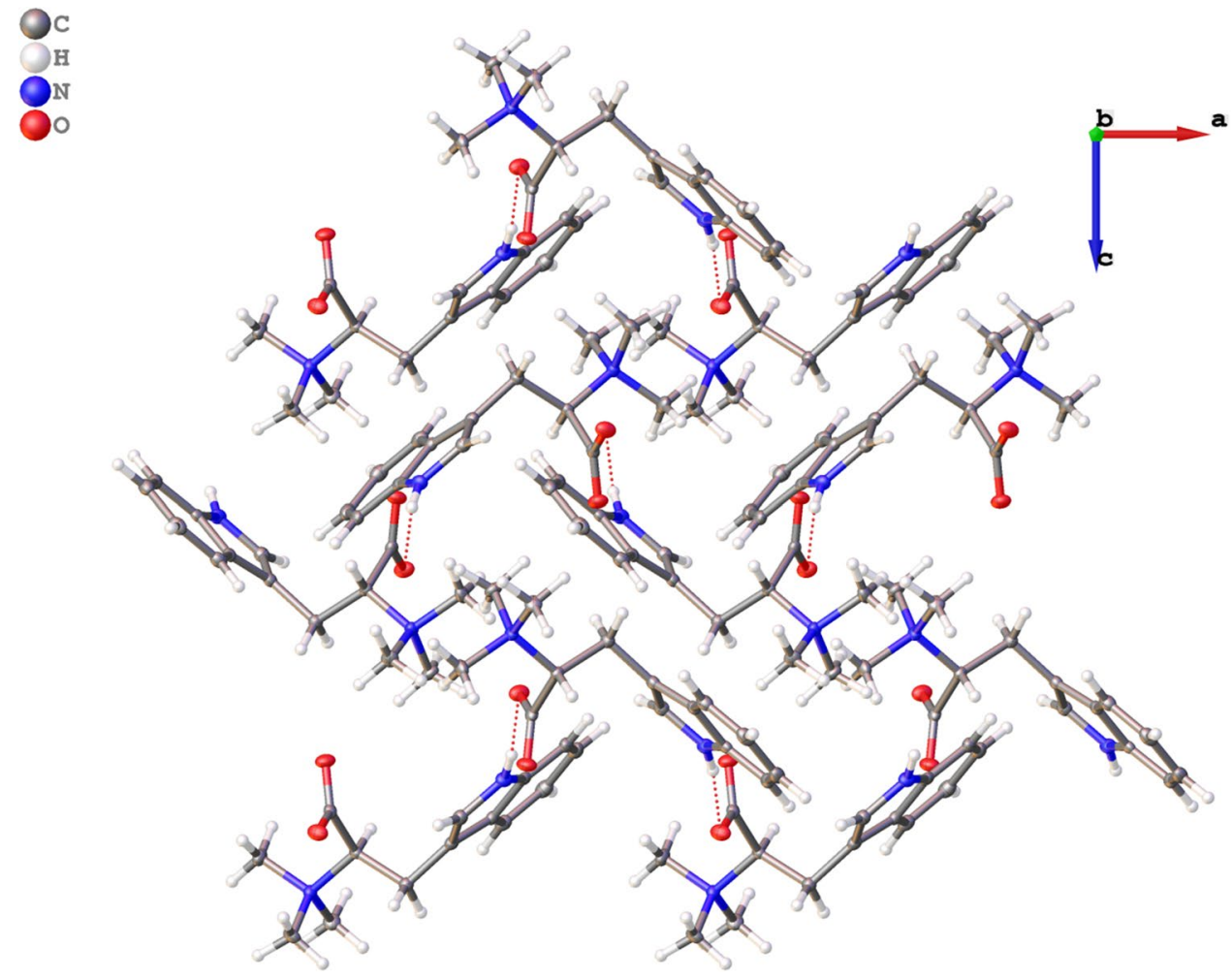

The remaining non-hydrogen atoms are located in an alternating series of least-squares cycles in the program SHELXL $[21,22]$ and difference Fourier maps. All nonhydrogen atoms were refined with anisotropic displacement coefficients unless specified otherwise. $\mathrm{C}$-bound $\mathrm{H}$ atoms are placed in geometrically idealized positions, with $\mathrm{C}-\mathrm{H}=0.93-0.99 \AA$, and are constrained to ride on their parent atoms with relative isotropic displacement coefficients, with $\mathrm{U}_{\text {iso }}(\mathrm{H})=1.2 \mathrm{U}_{\text {eq }}(\mathrm{C})$ for aromatic and methylene $\mathrm{H}$ atoms, and $\mathrm{U}_{\text {iso }}(\mathrm{H})=1.5 \mathrm{Ueq}(\mathrm{C})$ for methyl $\mathrm{H}$ atoms. The methyl $\mathrm{H}$ atoms were initially located in a different Fourier map, but since they are not involved in any hydrogenbonding interactions they are placed in idealized positions as described above and refined as rotating groups. $\mathrm{H}$ atoms on $\mathrm{N}$ atoms are also located in a different Fourier map and since they are involved in hydrogen bonding, the positions and isotropic displacement parameters of these atoms are allowed to refine freely.

The crystal structure was also refined as a racemic twin with a Flack $\times$ parameter of $0.3(13)$ indicating that the ratio of the two enantiomers in the crystal structure are approximately in the ratio of 30:70. A comprehensive search of the Cambridge Structural Database [38]—CSD 2019 release with February 2019 updates) of organic and organometallic crystal structures, for a crystal structure of hypaphorine yielded one result for the zwitterion structure (IZUTUU) our structure that we report here that had been submitted to the CSD as a private communication in 2016 [39].
Also, two related structures were published in CSD, namely L-6-Bromohypaphorine (BHYPOR) [40] and L-hypaphorine hydroiodide (PAMRUQ) [41].

The packing diagram of hypaphorine is depicted in (Fig. 2). The hypaphorine molecules pack end-to-end in layers diagonal to the packing axis (when viewed down the $b$-axis). When viewed exactly down the $b$-axis, molecules pack in an alternate stacking manner. This packing arrangement results from the hydrogen bonding that links these alternate layers through one strong hydrogen bond between $\mathrm{N}_{2}$ of the one molecule and $\mathrm{O} 2$ of the alternately stacked molecule. Figures 2 and 3 shows the hydrogen bonding interaction between two hypaphorine molecules-indicated by a dashed red line.

The optimized geometry of hypaphorine is illustrated in Figuere $2 \mathrm{~S}$ (supplementary material). The comparison of the calculated bond angles and bond lengths and the corresponding solid state values are listed in Table in $1 \mathrm{~S}$. The DFT data were compared with the X-ray data (Table 2, Fig. 4) and it was found that the root mean square deviation (RMSD) between the experimental and calculated bond lengths and bond angles of hypaphorine are found to be $0.046 \AA$ and $1.5^{\circ}$ respectively. The difference in values may be due to the fact that the experimental results were obtained at solid phase and the molecular rotations were restricted, while the theoretical results were obtained for a single molecule in the gas phase without any intermolecular interactions. 
Fig. 3 Molecular structure diagram of hypaphorine showing the strong hydrogen bond (indicated by dashed red line) that directs the packing
Fig. 4 Crystal structure of hypaphorine
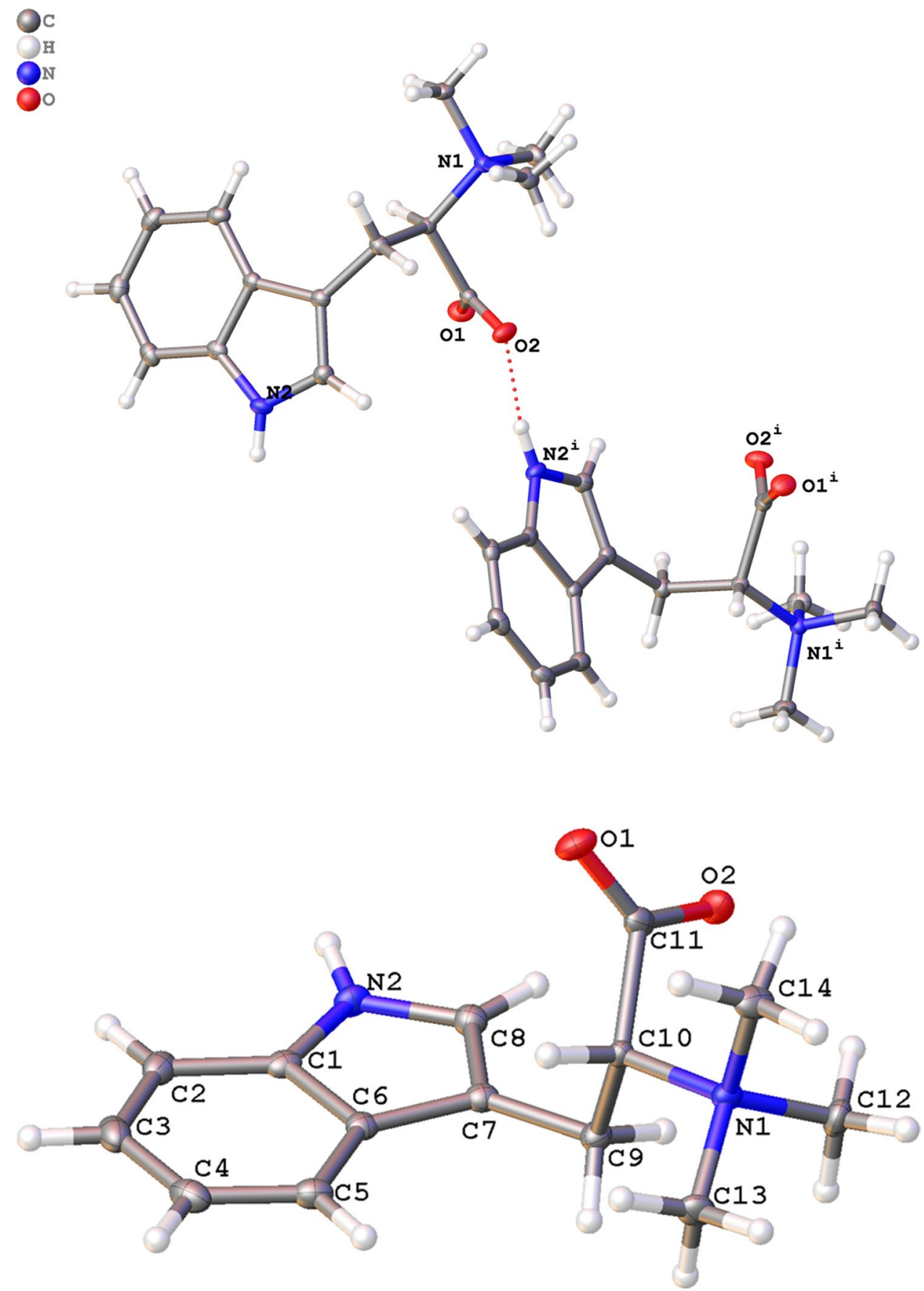

The frontier molecular orbitals and their characteristics are used to explain reactions in a conjugated system and to predict the reactive position in $\pi$-electron systems [42]. The highest occupied molecular orbital (HOMO) represents the ability to donate an electron and it is correlated to the ionization potential. The lowest occupied molecular orbital (LUMO) represents the ability to accept an electron which is correlated to electron affinity. The energy gap between the HOMO and LUMO levels is associated to molecular chemical stability $[43,44]$. The HOMO and LUMO surfaces of hypaphorine are illustrated in Fig. 5. The HOMO is delocalised in the indole moiety whereas the LUMO is delocalised on the $-\mathrm{N}\left(\mathrm{CH}_{3}\right)_{3}$ group. The HOMO-LUMO gap of hypaphorine is $4.65 \mathrm{eV}$ and the reactivity descriptors are also included Table 3. The natural charges on the atoms are provided in Table $2 \mathrm{~S}$.

The simulated IR spectrum of hypaphorine in the gas phase is presented in Fig. 6. Two stretching vibrations namely the uncorrected $\mathrm{N}-\mathrm{H}$ stretching and $\mathrm{C}=\mathrm{O}$ stretching are found at $3673 \mathrm{~cm}^{-1}$ and $1727 \mathrm{~cm}^{-1}$, respectively. 


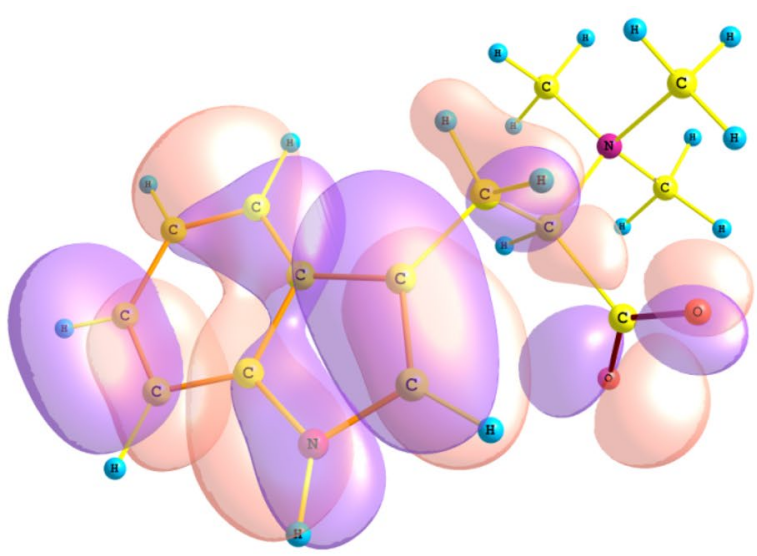

HOMO

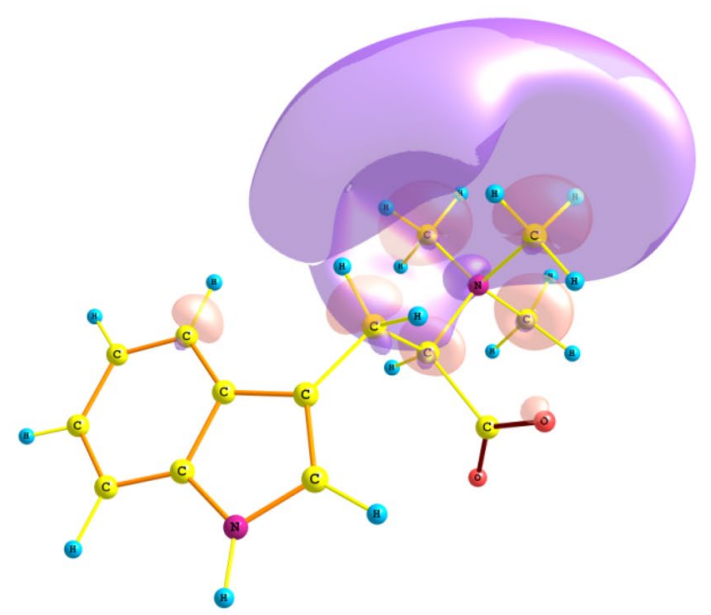

LUMO

Fig. 5 Frontier molecular orbitals of hypaphorine (HOMO and LUMO) computed in the gas phase

Table 3 Energy of HOMO and LUMO levels and derived reactivity descriptors of hypaphorine

\begin{tabular}{llr}
\hline Parameter & Equations & Value \\
\hline $\mathrm{E}_{\text {HOMO }}(\mathrm{eV})$ & & -5.61 \\
$\mathrm{E}_{\mathrm{LUMO}}(\mathrm{eV})$ & & -0.96 \\
HOMO-LUMO gap $(\mathrm{eV})$ & $\Delta \mathrm{E}=\mathrm{E}_{\mathrm{LUMO}}-\mathrm{E}_{\mathrm{HOMO}}$ & 4.65 \\
lonisation potential $(\mathrm{I})(\mathrm{eV})$ & $\mathrm{I}=-\mathrm{E}_{\mathrm{HOMO}}$ & 5.61 \\
Electron affinity $(\mathrm{A})(\mathrm{eV})$ & $\mathrm{A}=-\mathrm{E}_{\mathrm{LUMO}}$ & 0.96 \\
Electronegativity $(\chi)(\mathrm{eV})$ & $\chi=-\mu$ & 3.29 \\
Chemical potential $(\mu)(\mathrm{eV})$ & $\mu=-(\mathrm{I}+\mathrm{A}) / 2$ & -3.29 \\
Chemical hardness $(\eta)(\mathrm{eV})$ & $\eta=I-\mathrm{A}$ & 2.32 \\
Chemical softness $(\mathrm{S})(\mathrm{eV}-1)$ & $\mathrm{S}=1 / \eta$ & 0.22 \\
Electrophilicity index $(\omega)(\mathrm{eV})$ & $\omega=\mu^{2} / 2 \eta$ & 2.32 \\
\hline
\end{tabular}

\subsection{Antibacterial results}

The antibacterial assay results are presented in Table 4 . Pure hypaphorine inhibited the growth of all the Grampositive bacteria tested, namely Bacillus cereus, Bacillus subtilis, Staphylococcus aureus, Staphylococcus epidermidis and Mycobacterium smegmatis, except Enterococcus faecalis. It was found that hypaphorine did not affect the growth of any of the Gram-negative bacteria tested. Njamen and colleagues [36] found that pterocarpans from E. mildbraedii showed antimicrobial effects against Staphylococcus aureus, Mycobacterium smegmatis, Streptococcus mutans, and the Gram negative Porphyromonas gingivalis and Actinobacillus actinomycetemcomitans, indicating the
Fig. 6 Simulated IR spectrum of hypaphorine in the gas phase

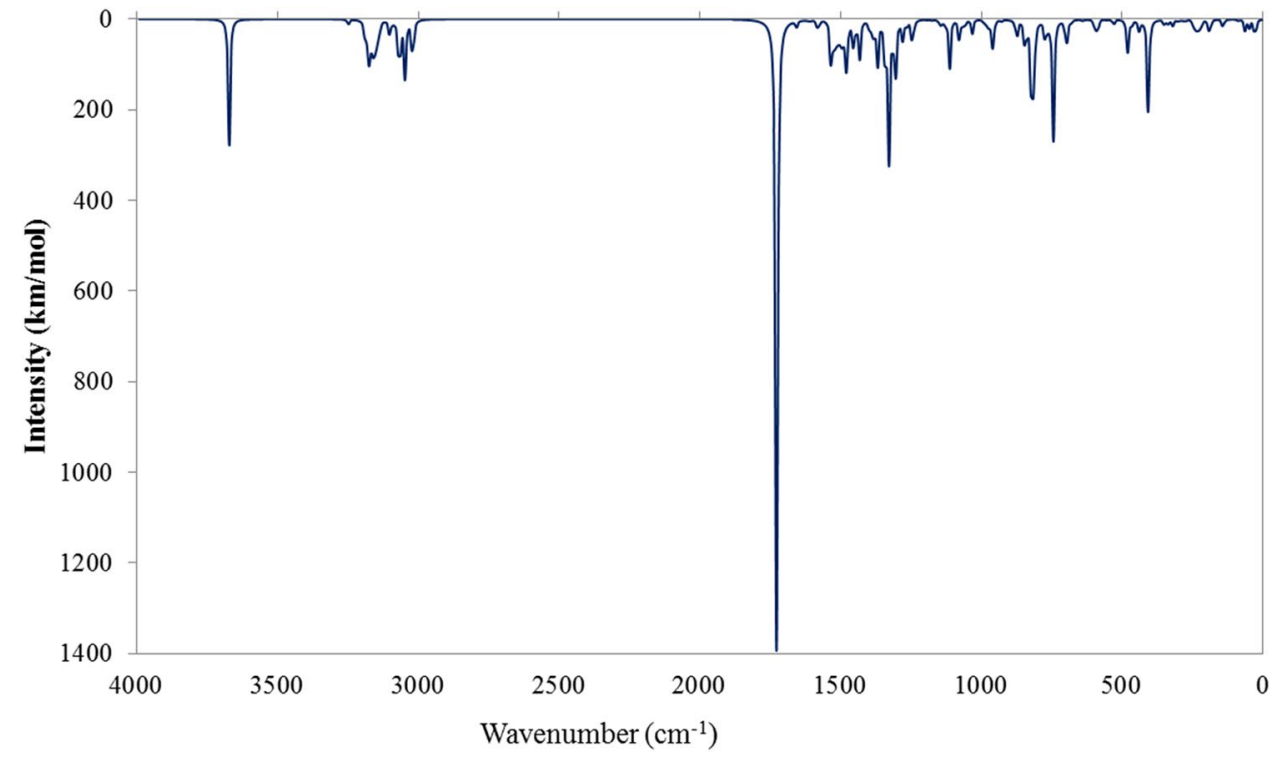


Table 4 Antibacterial characteristics of hypaphorine

\begin{tabular}{llll}
\hline Bacterial Strain & $\begin{array}{l}\text { Zone of Inhi- } \\
\text { bition }(\mathrm{mm})\end{array}$ & $\begin{array}{l}\mathrm{MIC}(\mathrm{mg} / \mathrm{mL}) \text { of } \\
\text { Hypaphorine }\end{array}$ & $\begin{array}{l}\mathrm{MIC}(\mathrm{mg} / \mathrm{mL}) \\
\text { of nalidixic } \\
\text { acid }\end{array}$ \\
\hline B. cereus & $10.9 \pm 1.2$ & 8 & 2 \\
B. subtilis & $21.9 \pm 0.7$ & 2 & Below 1 \\
M. smegmatis & $15.8 \pm 0.7$ & 4 & Above 16 \\
S. aureus & $12.1 \pm 0.9$ & 2 & 2 \\
S. epidermidis & $13.2 \pm 1.5$ & 4 & 2 \\
\hline
\end{tabular}

possibility for synergistic effects from a number of compounds found in the plant.

Tryptophan and arginine-rich peptides are known to have antimicrobial properties [44]. It has been proposed that tryptophan (structurally similar to hypaphorine) has a complicated interaction with the bilayer structure of membrane structures since it has a significant quadrupole moment that makes it hydrophilic, even though its structure suggests it should be hydrophobic. Tryptophan tends to locate itself in the interface region between the hydrophilic heads and hydrophobic tails in a membrane. Peptides rich in tryptophan and arginine can affect bacterial cells by either destabilizing the cell membrane or by binding to bacterial DNA and so block macromolecule replication [45].

Duponnois and Plenchette [13] proposed that bacteria in and around a mycorrhizal symbiotic relationship may stimulate hypaphorine production, but it may also be possible that the hypaphorine produced by either the plant or fungi may alter the bacterial populations in the mycorrhizosphere to suit them more. As such, the results in Table 4 are not too surprising considering that Gramnegative Pseudomonas bacteria are the dominant genus in the mycorrhizosphere of Pinus sylvestris-Suillus bovinus [46]. Other researchers $[46,47]$ found that general bacteria numbers are higher inside the mycorrhizosphere of various species of plants and fungi, probably due to the high concentration of organic matter to obtain nutrients from. Frey-Klett and colleagues [48] reported that Pseudomonas bacteria can mobilize iron or solubilize phosphorus from inorganic sources. In contrast, Barbieri and colleagues [49] found that Staphylococcus pasteuri bacteria released strong antifungal volatile organic compounds against Tuber borchii fungi. It would, therefore, appear that hypaphorine may play a role in maintaining the balance of specific Gram-negative and positive bacteria populations to suit the needs of the fungal symbionts in mycorrhizal relationships.

Of interest from this study is the fact that hypaphorine showed inhibitory properties against Mycobacterium smegmatis and Staphylococcus aureus. From Table 4, it
Table 5 Dipole moment, quadrupole moment, $\log \mathrm{P}$ and $\log \mathrm{S}$ of hypaphorine and tryptophan

\begin{tabular}{lccc}
\hline & Hypaphorine & Tryptophan & nalidixic acid \\
\hline Dipole moment (D) & 8.177 & 3.073 & \\
Quadrupole moment & -15.640 & -5.191 & \\
$\quad(D \AA)$ & & & \\
$\log P^{a}$ & -0.54 & -1.10 & 0.95 \\
$\log S^{a}$ & -5.07 & -2.18 & -2.00 \\
\hline
\end{tabular}

${ }^{\mathrm{a}} \log \mathrm{P}$ and $\log \mathrm{S}$ were estimated using ALOGPS 2.1 [55]

seems that mainly Gram-positive bacteria are susceptible to the compound. Mycobacterium tuberculosis is the causative agent of TB and since 2013, the WHO has estimated that 9 million people fell ill with TB and that over a million died from the disease [50]. TB is the second largest killer after HIV; moreover, TB/HIV co-infections have been a regular feature in countries plagued by the HIV. Methicillinresistant Staphylococcus aureus (MRSA), is also responsible for life-threatening infections usually acquired in major hospitals and other health care facilities [51].

Whilst several studies have previously looked at antibacterial activities of crude plant extracts from Erythrina species $[36,51,52]$ showed that isoflavonoids from Erythrina variegata are potent against MRSA with MIC values below $100 \mu \mathrm{g} / \mathrm{mL}$. From Table 4, it can be noted that hypaphorine has a much lower potency at $2000 \mu \mathrm{g} / \mathrm{mL}$ against S. aureus which is not comparable to the above mentioned isoflavonoids. Arpha and colleagues [53] came to a similar conclusion when testing hypaphorine against $M$. tuberculosis, with an MIC above $50 \mathrm{mg} / \mathrm{mL}$. This leaves scope for investigating the synergistic effects of compounds such as hypaphorine and isoflavonoids against problematic bacterial strains. Possible additional compounds with lesser side effects could be useful for future therapeutic applications. It is known that hypaphorine is related to the naturally occurring indole-3-acetic acid; possible synthetic structural analogs can be generated and evaluated to further heighten bioactive properties against MRSA and $M$. tuberculosis.

Dipole moment, quadrupole moment, hydrophobicity $(\log \mathrm{P})$ and solubility in water (logS) have been used as molecular parameters to relate to biological properties of compounds [54,55]. The estimated values of these parameters for hypaphorine and tryptophan are collected in Table 5. It can be deduced that hypaphorine has a larger dipole moment and quadrupole moment than tryptophan. Hypaphorine is also expected to be less hydrophobic and has lower solubility in water than tryptophan. 


\section{Conclusion}

Hypaphorine was isolated from E. addisoniae and E. mildbraedii. The structure of hypaphorine shows that the nonpolar double ring structure tends to lie on one plane and a polar carboxyl group stands out from that plane, allowing for a quadrupole moment. In theory this should allow hypaphorine to have similar antibacterial effects as tryptophan that is, it should be capable of inserting itself into the bilayer structure of bacterial cell membranes where it can disrupt the membranes.

The ecological impact of hypaphorine in a symbiotic context with bacteria and fungi will have to be investigated. A clear determination will have to be made of where it is originally produced-in the fungal hyphae, plant roots or simultaneously in both. Tests will have to be done on how the presence of hypaphorine influences subsequent production levels in both symbionts, if and how hypaphorine is transported in both symbionts, and how the presence of hypaphorine affects the population numbers of mixed soil bacteria.

For the medicinal properties of hypaphorine, future studies will be to investigate the actual mechanisms by which it affects both $M$. smegmatis and $S$. aureus and also studying the compound's effects on the actual M. tuberculosis and MRSA. By identifying small molecules from the natural (or synthetic) products arsenal against pathogenic bacteria, a window of opportunity is opened to gain insights into bioactive compounds destined against problematic microbes.

Acknowledgements This work was supported by the University of Johannesburg FRC/URC fund 2015, the National Research Foundation (NRF) under Grant Number 99704 and the Centre for Nano Materials Science Research, University of Johannesburg.

\section{Compliance with ethical standards}

Conflict of interest The authors declare that they have no conflict of interest.

\section{References}

1. Béguiristain T, Lapeyrie F (1997) Host plant stimulates hypaphorine accumulation in Pisolithus tinctorius hyphae during ectomycorrhizal infection while excreted fungal hypaphorine controls root hair development. New Phytol 136:525-532. https://doi.org/10.1046/j.1469-8137.1997.00753.x

2. Rukachaisirikul T, Innok P, Aroonrerk N, Boonamnuaylap W, Limrangsun S, Boonyon C, Woonjina U, Suksamrarn A (2007) Antibacterial pterocarpans from Erythrina subumbrans. J Ethnopharmacol 110:171-175. https://doi.org/10.1016/j. jep.2006.09.022
3. Folkers K, Koniuszy F (1940) Erythrina Alkaloids. VII. Isolation and characterization of the new alkaloids, erythraline and erythratine. J Am Chem Soc 62:436-441. https://doi.org/10.1021/ ja01859a054

4. Keller BO, Wu BTF, Li SSJ, Monga V, Innis SM (2013) Hypaphorine is present in human milk in association with consumption of legumes. J Agric Food Chem 61:7654-7660. https://doi. org/10.1021/jf401758f

5. Ozawa M, Honda K, Nakai I, Kishida A, Ohsaki A (2008) Hypaphorine, an indole alkaloid from Erythrina velutina, induced sleep on normal mice. Bioorg Med Chem Lett 18:3992-3994. https://doi. org/10.1016/j.bmcl.2008.06.002

6. Reboutier D, Bianchi M, Brault M, Roux C, Dauphin A, Rona J-P, Legue V, Lapeyrie F, Bouteau F (2002) The indolic compound hypaphorine produced by ectomycorrhizal fungus interferes with auxin action and evokes early responses in nonhost Arabidopsis thaliana. Mol Plant Microbe Interact 15:932-938. https:// doi.org/10.1094/MPMI.2002.15.9.932

7. Ditengou FA, Raudaskoski M, Lapeyrie F (2003) Hypaphorine, an indole-3-acetic acid antagonist delivered by the ectomycorrhizal fungus Pisolithus tinctorius, induces reorganisation of actin and the microtubule cytoskeleton in Eucalyptus globulus ssp bicostata root hairs. Planta 218:217-225. https://doi. org/10.1007/s00425-003-1095-3

8. Dalmazzo LFF, Santana-Lemos BA, Jácomo RH, Garcia AB, Rego EM, da Fonseca LM, Falcão RP (2011) Antibody-targeted horseradish peroxidase associated with indole-3-acetic acid induces apoptosis in vitro in hematological malignancies. Leuk Res 35:657-662. https://doi.org/10.1016/j.leukres.2010.11.025

9. Hussain MM, Tuhin MTH, Akter F, Rashid MA (2016) Constituents of Erythrina - a potential source of secondary metabolities: a review. Bangladesh Pharm J 19:237-253. https://doi. org/10.3329/bpj.v19i2.29287

10. Herrera-martínez A, Ruiz-medrano R, Galván-gordillo SV, Toscano-morales R, Gómez-Silva L, Valdés M, Hinojosa-Moya J, Xoconostle-Cázares B (2014) A 2-component system is involved in the early stages of the Pisolithus tinctorius-Pinus greggii symbiosis. Plant Signal Behav 9:1-12

11. Beguiristain T, Cote R, Rubini P, Jay-Allemand C, Lapeyrie F (1995) Hypaphorine accumulation in hyphae of the ectomycorrhizal fungus, Pisolithus tinctorius. Phytochemistry 40:1089-1091. https://doi.org/10.1016/0031-9422(95)00445-D

12. Nguyen QNN, Tantillo DJ (2014) The many roles of quantum chemical predictions in synthetic organic chemistry. Chem An Asian J 9:674-680. https://doi.org/10.1002/asia.201301452

13. Duponnois R, Plenchette C (2003) A mycorrhiza helper bacterium enhances ectomycorrhizal and endomycorrhizal symbiosis of Australian Acacia species. Mycorrhiza 13:85-91. https:// doi.org/10.1007/s00572-002-0204-7

14. Cheng GJ, Zhang X, Chung LW, Xu L, Wu YD (2015) Computational organic chemistry: bridging theory and experiment in establishing the mechanisms of chemical reactions. J Am Chem Soc 137:1706-1725. https://doi.org/10.1021/ja5112749

15. Li Y (2015) Structural revision of glabramycins B and C, antibiotics from the fungus Neosartorya glabra by DFT calculations of NMR chemical shifts and coupling constants. RSC Adv 5:36858-36864. https://doi.org/10.1039/c5ra01753j

16. Nguyen PH, Sharma G, Dao TT, Uddin MN, Kang KW, Ndinteh DT, Mbafor JT, Oh WK (2012) New prenylated isoflavonoids as protein tyrosine phosphatase 1B (PTP1B) inhibitors from Erythrina addisoniae. Bioorg Med Chem 20:6459-6464. https ://doi.org/10.1016/j.bmc.2012.08.024

17. Talla E, Yankep E, Mbafor JT (2014) Chemical constituents from roots of Erythrina mildbraedi and stem barks of Erythrina addisoniae. Bull Chem Soc Ethiop 28:155-159. https://doi.org/10. 1111/j.1551-2916.2008.02578.x 
18. Wandji J, Awanchiri S, Tanee Fomum Z, Tillequin F, Libot F (1995) Isoflavones and alkaloids from the stem bark and seeds of Erythrina senegalensis. Phytochemistry 39:677-681. https:// doi.org/10.1016/0031-9422(94)00779-S

19. Sarragiotto MH, Filho HL, Marsaioli AJ (1981) Erysotrine-Noxide and erythrartine-N-oxide, two novel alkaloids from Erythrina mulungu. Can J Chem 59:2771-2775

20. SAINT, SADABS (2012) Bruker APEXII

21. Sheldrick GM (2008) A short history of SHELX. Acta Crystallogr Sect A: Found Crystallogr 64:112-122. https://doi. org/10.1107/S0108767307043930

22. Sheldrick GM (2015) Crystal structure refinement with SHELXL. Acta Crystallogr Sect C Struct Chem 71:3-8. https://doi. org/10.1107/S2053229614024218

23. Dolomanov OV, Bourhis LJ, Gildea RJ, Howard JAK, Puschmann H (2009) OLEX2: a complete structure solution, refinement and analysis program. J Appl Crystallogr 42:339-341. https:// doi.org/10.1107/S0021889808042726

24. Spek AL (2009) Structure validation in chemical crystallography. Acta Crystallogr Sect D: Biol Crystallogr 65:148-155. https ://doi.org/10.1107/S090744490804362X

25. Othman M, Loh HS, Wiart C, Khoo TJ, Lim KH, Ting KN (2011) Optimal methods for evaluating antimicrobial activities from plant extracts. J Microbiol Methods 84:161-166

26. Andrews JM (2001) Determination of minimum inhibitory concentrations. J Antimicrob Chemother 48(Suppl 1):5-16

27. Becke AD (1993) Density-functional thermochemistry. III. The role of exact exchange. J Chem Phys 98:5648-5652. https:// doi.org/10.1063/1.464913

28. Lee C, Yang W, Parr RG (1988) Development of the ColleSalvetti correlation-energy formula into a functional of the electron density. Phys Rev B: Condens Matter 37:785-789

29. Krishnan R, Binkley JS, Seeger R, Pople JA (1980) Self-consistent molecular orbital methods. XX. A basis set for correlated wave functions. J Chem Phys 72:650-654. https://doi. org/10.1063/1.438955

30. Tomasi J, Persico M (1994) Molecular interactions in solution: an overview of methods based on continuous distributions of the solvent. Chem Rev 94:2027-2094. https://doi.org/10.1021/ cr00031a013

31. Simkin BY, Sheikhet I (1995) Quantum chemical and statistical theory of solutions-a computational approach. Ellis Horwood, London

32. Wolinski K, Hinton JF, Pulay P (1990) Efficient implementation of the gauge-independent atomic orbital method for NMR chemical shift calculations. J Am Chem Soc 112:8251-8260. https:// doi.org/10.1021/ja00179a005

33. Frisch MJ, Trucks GW, Schlegel HB, Scuseria GE, Robb MA, Cheeseman JR, Scalmani G, Barone V, Mennucci B, Petersson GA, Nakatsuji H, Caricato M, Li X, Hratchian HP, Izmaylov AF, Bloino J, Zheng G, Sonnenberg JL, Hada M, Ehara M, Toyota K, Fukuda $R$, Hasegawa J, Ishida M, Nakajima T, Honda Y, Kitao O, Nakai $H$, Vreven T, Montgomery JA, Jr. JEP, Ogliaro F, Bearpark M, Heyd JJ, Brothers E, Kudin KN, Staroverov VN, Kobayashi R, Normand J, Raghavachari K, Rendell A, Burant JC, Iyengar SS, Tomasi J, Cossi M, Rega N, Millam JM, Klene M, Knox JE, Cross JB, Bakken V, Adamo C, Jaramillo J, Gomperts R, Stratmann RE, Yazyev O, Austin AJ, Cammi R, Pomelli C, Ochterski JW, Martin RL, Morokuma K, Zakrzewski VG, Voth GA, Salvador P, Dannenberg JJ, Dapprich S, Daniels AD, Farkas Ö, Foresman JB, Ortiz JV, Cioslowski J, Fox DJ (2009) GAUSSIAN 09, Revision D.01

34. Dooley R, Milfeld K, Guiang C, Pamidighantam S, Allen G (2006) From proposal to production: lessons learned developing the computational chemistry Grid cyberinfrastructure. J Grid Comput 4:195-208. https://doi.org/10.1007/s10723-006-9043-7
35. Shen N, Fan Y, Pamidighantam S (2014) E-science infrastructures for molecular modeling and parametrization. J Comput Sci 5:576-589. https://doi.org/10.1016/j.jocs.2014.01.005

36. Njamen D, Talla E, Mbafor JT, Fomum ZT, Kamanyi A, Mbanya J-C, Cerdá-Nicolás M, Giner RM, Recio MC, Ros JL (2003) Antiinflammatory activity of erycristagallin, a pterocarpene from Erythrina mildbraedii. Eur J Pharmacol 468:67-74. https://doi. org/10.1016/S0014-2999(03)01664-9

37. Tchokouaha RF, Alexi $X$, Chosson E, Besson T, Skaltsounis A-L, Seguin E, Alexis MN, Wandji J (2010) Erymildbraedin A and B, two novel cytotoxic dimethylpyrano-isoflavones from the stem bark of Erythrina mildbraedii: evaluation of their activity toward endocrine cancer cells. J Enzyme Inhib Med Chem 25:228-233. https://doi.org/10.3109/14756360903169972

38. Allen $F(2002)$ The Cambridge Structural Database: a quarter of a million crystal structures and rising. Acta Crystallogr Sect B 58:380-388

39. Arderne C, Ndinteh TD (2016) CCDC 1401794: experimental crystal structure determination. https://doi.org/10.5517/ccdc. csd.cc1j1p5f

40. Raverty WD, Thomson RH, King TJ (1977) Metabolites from the sponge Pachymatisma johnstoni; L-6-bromohypaphorine, a new amino-acid (and its crystal structure). J Chem Soc Perkin Trans 1:1204-1211. https://doi.org/10.1039/P19770001204

41. Jones GP, Tiekink ERT (1997) Crystal and molecular structure of I-hypaphorine hydroiodide. Zeitschrift für Krist Cryst Mater 212:881

42. Kurt M, Babu PC, Sundaraganesan N, Cinar M, Karabacak M (2011) Molecular structure, vibrational, UV and NBO analysis of 4-chloro-7-nitrobenzofurazan by DFT calculations. Spectrochim Acta A Mol Biomol Spectrosc 79:1162-1170. https://doi. org/10.1016/j.saa.2011.04.037

43. Montezano AC, Touyz RM (2012) Oxidative stress, Noxs, and hypertension: experimental evidence and clinical controversies. Ann Med 44(Suppl 1):S2-S16. https://doi.org/10.3109/07853 890.2011 .653393

44. Chan DI, Prenner EJ, Vogel HJ (2006) Tryptophan- and argininerich antimicrobial peptides: structures and mechanisms of action. Biochim Biophys Acta Biomembr 1758:1184-1202. https ://doi.org/10.1016/j.bbamem.2006.04.006

45. Haney EF, Petersen AP, Lau CK, Jing W, Storey DG, Vogel HJ (2013) Mechanism of action of puroindoline derived tryptophan-rich antimicrobial peptides. Biochim Biophys Acta Biomembr 1828:1802-1813. https://doi.org/10.1016/j.bbame m.2013.03.023

46. Timonen S, Jørgensen KS, Haahtela K, Sen R (1998) Bacterial community structure at defined locations of Pinus sylvestrisSuillus bovinus and Pinus sylvestris-Paxillus involutus mycorrhizospheres in dry pine forest humus and nursery peat. Can J Microbiol 44:499-513. https://doi.org/10.1139/w98-035

47. Andrade G, Linderman RG, Bethlenfalvay GJ (1998) Bacterial associations with the mycorrhizosphere of the arbuscular mycorrhizal fungus Glomus mosseae. Plant Soil 202:79-87. https:// doi.org/10.1023/A:1004397222241

48. Frey-Klett P, Garbaye J, Tarkka M (2007) The mycorrhiza helper bacteria revisited. New Phytol 176:22-36. https://doi.org/10.11 11/j.1469-8137.2007.02191.x

49. Barbieri E, Gioacchini AM, Zambonelli A, Bertini L, Stocchi V (2005) Determination of microbial volatile organic compounds from Staphylococcus pasteuri against Tuber borchii using solidphase microextraction and gas chromatography/ion trap mass spectrometry. Rapid Commun Mass Spectrom 19:3411-3415. https://doi.org/10.1002/rcm.2209

50. WHO (2015) World Health Organisation Fact sheet no. 104-Tuberculosis 
51. Tanaka H, Sato M, Fujiwara S, Hirata M, Etoh H, Takeuchi H (2002) Antibacterial activity of isoflavonoids isolated from Erythrina variegata against methicillin-resistant Staphylococcus aureus. Lett Appl Microbiol 35:494-498. https://doi.org/10.1046/j.1472765X.2002.01222.x

52. De Araújo-júnior JX, De Oliveira MSG, Aquino PGV, Alexandremoreira MS, Ana AEGS (2008) A phytochemical and ethnopharmacological review of the genus Erythrina. Intech 1:327-352. https://doi.org/10.5772/26997

53. Arpha K, Phosri C, Suwannasai N, Mongkolthanaruk W, Sodngam S (2012) Astraodoric acids A-D: new lanostane triterpenes from edible mushroom Astraeus odoratus and their anti-mycobacterium tuberculosis H37Ra and cytotoxic activity. J Agric Food Chem 60:9834-9841. https://doi.org/10.1021/jf302433r
54. Tetko IV, Tanchuk VY (2002) Application of associative neural networks for prediction of lipophilicity in ALOGPS 2.1 program. J Chem Inf Comput Sci 42:1136-1145. https://doi.org/10.1021/ ci025515j

55. Karelson M, Lobanov VS, Katritzky AR (1996) Quantum-chemical descriptors in QSAR/QSPR Studies. Chem Rev 96:1027-1044. https://doi.org/10.1021/cr950202r

Publisher's Note Springer Nature remains neutral with regard to jurisdictional claims in published maps and institutional affiliations. 